\title{
They Shall Not Grow Old: can a film about the First World War help recruitment to geriatrics?
}

\author{
Christopher Frank ${ }^{1}$ (1)
}

Received: 4 November 2019 / Accepted: 6 December 2019 / Published online: 17 December 2019

(c) European Geriatric Medicine Society 2019

I once asked a 93-year-old patient if he had ever been dizzy and he replied, "Yes, but I'd just been blown up by a hand grenade. We were fighting the Japanese you know". I enjoy working with older patients because of the tangible link to the past they provide, and I know I am not alone in this. We have all met patients who were present at famous events and it does provide a little thrill to be connected, even indirectly, to embodied history through our work.

When I first started to practice geriatrics in Canada in the early 1990s, First World War veterans were still alive. John Babcock, the last Canadian born veteran of the First World War, died in 2010 at age 109, having tried to enlist at age 15. Gladys Powers, the last Canadian woman to serve, died in 2008. She was in a non-combat role before moving to Canada from England in 1920. During my early career, I met many people with similar stories, and I heard of their experiences in France or elsewhere. I also met a 100-year old-lady who had been in Sarajevo the day that Archduke Ferdinand was assassinated; she remembered a very ordinary day.

Second World War veterans were very common then and I cared for former spies, survivors of Stalingrad, and Resistance fighters. Now, the number of Second World War veterans is dwindling but I still see people who experienced that cataclysm. Many of them remain quite indomitable and often their past experiences guide how they approach illness and frailty. More recently, a very gentle 94-year-old with terminal cancer described his time as a demolition expert in a paratroop battalion, "blowing up anything that moved, particularly trains".

I try to interest trainees in the stories their older patients can tell, as this can be relevant to the approach they take to care and can forge understanding and build rapport [1].

Christopher Frank

frankc@providencecare.ca

1 Department of Medicine, Division of Geriatric Medicine, Providence Care Hospital, Queen's University, 752 King St. West, Kingston, ON K7L 4X3, Canada
Hopefully enthusiasm for this connection to history may generate interest in geriatric-focused fields of healthcare, as geriatricians (and others in geriatric-focused fields) often trace their career choice to encounter with older people, such as grandparents [2]. It is sobering to realize that I am now old enough that events I have experienced would be considered "history" by medical students! Although there is a literature about choice of geriatrics as a career, little attention has been paid to the potential role of the humanities. We have published about the possible impact on recruitment to geriatric-focused fields, but most of the evidence is anecdotal [3].

Even for an experienced physician like me it can be difficult to extrapolate from the frail patient in the hospital bed back to their younger self, engaging in arduous and terrifying roles many years ago. This must be even harder for younger clinicians. Humanities like history, film, or photography can fuel the imagination and can help bridge this distance. Any creative work that reminds younger trainees that the frail person in front of them was once vital and has a lifetime of experiences has the potential to inspire them to care for older people and even to choose to choose a career in geriatrics.

The director Peter Jackson has produced a work of great interest to anyone interested in history and one that could be of relevance to efforts to use connection to the past to attract trainees to geriatric-focused fields. His recent film They Shall Not Grow Old uses new techniques to revitalize vintage film from the First World War and make it clear to a younger audience watching the film in the present time that the young people filmed over 100 years ago were actually not that different. Especially in this age of high definition video taken from phones, footage from the First World War often separates us from the participants because they are in black and white, are silent, and move in a jerky and unnatural fashion. The subjects appear to be not only from a different era, but from an entirely different species. This 
same sense of difference can distance older patients from younger trainees.

They Shall Not Grow Old was inspired by Jackson's personal relationship to the War; his grandfather was wounded at the Somme and shipped back to Britain, where he met his future wife. The old film, taken from $100 \mathrm{~h}$ of badly damaged footage from the Imperial War Museums, was colourized with an effort to match colours with historical accuracy. Importantly, the speed is changed from 10 to 12 frames per second and interstitial frames added to make the soldiers move naturally and look contemporary. As Jackson says, the process helps the soldiers "regain their humanity rather than being seen as Charlie Chaplin-like figures in the vintage archive films". Many of the scenes are quite cinematic given the film quality and editing, which helps makes them more real to the viewer. Even more interestingly, the soldiers are given voice. Professional lip readers reviewed the footage and provided an accurate transcript of what was said a 100 years ago. Veterans recorded in the 1950s provide voice overs to heighten the link to the real experiences of the young people shown at war. They often reminisce about happy and pleasurable times, not just the horrors.

Clearly, screening They Shall Not Grow Old for all medical students will not solve the human health resource issues that plague geriatric-focused fields. However, I believe it reminds us that there are many things that influence how ageing is viewed and valued. Reminding trainees that old and frail people have survived tumultuous times may help prompt them to seek and interact with older patients. In Jackson's film, it is clear that although older people have lived very different lives, their quips and comments, gestures, and interactions as young people in the film are universal. The more we help younger clinicians and trainees to be inspired by the history our older patients have been part of, the more compassionate and rewarding clinical encounters can be.

\section{Compliance with ethical standards}

Conflict of interest The corresponding author states that there is no conflict of interest.

Ethical approval This article does not contain any studies with human participants or animals performed by any of the authors.

Informed consent For this type of article formal consent is not required.

\section{References}

1. Frank CC (2019) Tell me a story: using narrative history with older patients. In: Project assets. https://www.cfpc.ca/ProjectAss ets/Templates/Resource. aspx?id=5865. Accessed 17 July 2019

2. Blachman NL, Blaum CS, Zabar S (2019) Reasons geriatrics fellows choose geriatrics as a career, and implications for workforce recruitment. Geront Geriatr Educ. https://doi.org/10.1080/02701 960.2019.1604341

3. Frank CC, Martin RE (2015) Humanities and geriatric education: a strategy for recruitment. Can Geriatr J 18(1):37-41. https://doi. org/10.5770/cgj.18.137

Publisher's Note Springer Nature remains neutral with regard to jurisdictional claims in published maps and institutional affiliations. 